\title{
НАУКОВО-МЕТОДИЧНИЙ СУПРОВІД ВПРОВАДЖЕННЯ СТАНДАРТИЗОВАНИХ ПІДХОДІВ ДО ПРОФІЛАКТИКИ СЕРЦЕВО-СУДИННИХ ЗАХВОРЮВАНЬ У ПРАКТИЧНУ ДІЯЛЬНІСТЬ ДЕРЖАВНОЇ НАУКОВОЇ УСТАНОВИ «НАУКОВО-ПРАКТИЧНИЙ ЦЕНТР ПРОФІЛАКТИЧНОЇ ТА КЛІНІЧНОЇ МЕДИЦИНИ" ДЕРЖАВНОГО УПРАВЛІННЯ СПРАВАМИ
}

Державна наукова установа «Науково-практичний центр профілактичної та клінічної медицини» Державного управління справами, Київ

\section{Резюме}

Мета - оптимізація заходів профілактики серцево-судинних захворювань (СС3) у Аержавній науковій установі «Науково-практичний центр профілактичної та клінічної медицини» Аержавного управління справами (АНУ «НПЦ ПКМ» АУС) у віАповідності до вимог доказової медицини шляхом розробки та впровадження локального протоколу медичної допомоги ( $А$ ПМ $А$ «Профілактика серцево-судинних захворювань».

Матеріал і методи. Аосліджено поширеність чинників ризику (ЧР) ССЗ серед 210 державних

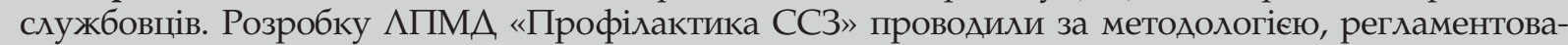
ною Наказом МОЗ України від 28.09.2012 р. № 751, з урахуванням потреб і можливостей закладу. Результати. За результатами анкетного опитування в $54,28 \pm 3,44 \%$ випадків державні службовці оцінили виконання рекомендацій щодо здорового способу життя та профілактики захворювань за п'ятибальною шкалою на 3 бали та нижче. Серед ЧР ССЗ найпоширенішими виявилися такі поведінкові ЧР, як недостатнє вживання основних продуктів здорового харчу-

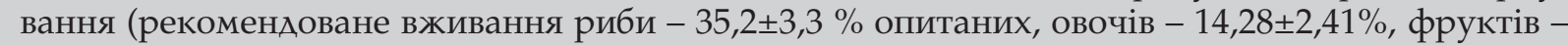

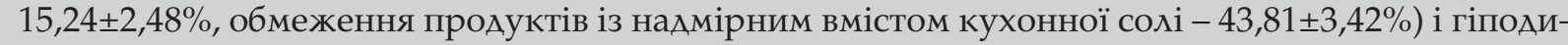
намія $(59,05 \pm 3,4 \%)$. У ході розробки $\Lambda$ ПМА основну увагу було приділено заходам визначення, корекції та моніторингу ЧР ССЗ лікарями на всіх етапах медичної допомоги. Ао переліку обов'язкових заходів увійшли підтримка мотивації пацієнта на виконання рекомендацій щодо здорового способу життя, медикаментозного лікування та досягнення оптимального контролю ЧР.

Висновки. У АНУ «НПЦ ПКМ» АУС вперше в Україні з використанням переваг електронно-

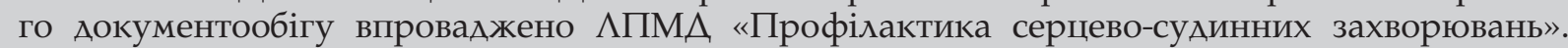
Запропоновані положення $\Lambda$ ПА використано для розробки Уніфікованого клінічного протоколу медичної допомоги, затвердженого Наказом МО3 України 13.06.2016 p. № 564.

Ключові слова: профілактика серцево-судинних захворювань, чинники ризику, хокальний протокол медичної допомоги.

\section{ВСТУП}

Профілактичний напрямок визначено як пріоритетний у роботі Державної наукової установи «Науково-практичний центр профілактичної та клінічної медицини» Державного управління справами (ДНУ «НПЦ ПКМ» ДУС). Актуальність про- блеми впровадження заходів профілактики серцево-судинних захворювань (СС3) із доведеною ефективністю обумовлено значним внеском хвороб системи кровообігу в структуру причин смерті.

Мета дослідження - оптимізація заходів профілактики ССЗ у ДНУ «НПЦ ПКМ» ДУС у відповід- 
ності до вимог доказової медицини шляхом розробки та впровадження локального протоколу медичної допомоги (ЛПМД) «Профілактика серцевосудинних захворювань».

\section{МАТЕРІАЛ I МЕТОДИ}

Дослідження поширеності чинників ризику (ЧР) ССЗ проводили шляхом анкетування та комплексного клінічного обстеження репрезентативної вибірки 210 державних службовців. Контрольну групу склали 40 лікарів ДНУ «НПЦ ПКМ» ДУС. Для оцінки стадії готовності до змін поведінкових ЧР СС3 проводили анкетне опитування 158 пацієнтів випадкової вибірки, які проходили профілактичний огляд у ДНУ «НПЦ ПКМ» ДУС. Середній вік обстежених $-43,0 \pm 10,3$ року.

Для стандартизації підходів до визначення поширеності ЧР СС3 розроблено анкети соціологічного опитування (Додаток 1). Для визначення стадії готовності пацієнта до змін трьох складових нездорової поведінки - тютюнокуріння, нездорового харчування, низького рівня фізичної активності - запропоновано опитувальник, який включає три блоки питань. Пріоритетність використання запропонованого опитувальника підтверджено Патентом на корисну модель (11 4960 U Україна, опубл. 27.03.2017, Бюл. №6). Варіанти відповідей на питання грунтуються на засадах транстеоретичної моделі готовності до змін [1].

Розробку ЛПМД «Профілактика ССЗ» проводили згідно з методологією, регламентованою Наказом MO3 України [2]. Вона та включала такі етапи:

1. Вивчення змісту клінічних настанов щодо профілактики СС3, розроблених на державному та міжнародному рівнях.

2. Ситуаційний аналіз можливості виконання положень настанов у ДНУ «НПЦ ПКМ» ДУС.

3. Наповнення текстової та графічної частини ЛПМД.

Результати анкетного опитування та результати обстежень було внесено в сформовану комп'ютерну базу даних. Первинну підготовку таблиць і проміжні розрахунки проводили на персональному комп'ютері з використанням програмного пакету Microsoft Excel. Статистичний аналіз здійснювали на персональному комп'ютері за допомогою прикладних програм статистичного аналізу Microsoft Excel, статистичних пакетів STATISTICA 6.0. Для змінних шкали відношень первинна обробка включала розрахунок середніх арифметичних (M) i помилок середніх арифметичних (m). Для змінних найменувань і рангових змінних первинна обробка включала в себе розрахунок відсотків (Р).

\section{РЕЗУЛЬТАТИ ТА ОБГОВОРЕННЯ}

Сучасні вимоги доказової медицини до профілактики СС3 регламентують визначення ЧР СС3 та їх корекцію, яка включає дотримання здорового способу життя та медикаментозне лікування. Вирішення цього завдання вимагає комплексного підходу й активної участі як лікарів, так і пацієнтів, і підвищення поінформованості щодо питань профілактики.

На першому етапі було проведено комплексну оцінку поширеності ЧР СС3 серед державних службовців [3]. Результати дослідження засвідчили високу поширеність ЧР СС3 серед державних службовців різного віку, що в цілому відповідає аналогічним показникам української популяції. Визначено високий рівень поширеності ЧР, пов'язаних зі способом життя: звичка тютюнокуріння притаманна $16,7 \pm 2,6 \%$, поширеність гіподинамії становить $59,05 \pm 3,4 \%$. Не визначено вірогідної різниці в поширеності тютюнокуріння та гіподинамії серед державних службовців різного віку та статі. Для державних службовців типовим є брак вживання основних продуктів, які характеризують здорове харчування - рекомендоване вживання риби два та більше разів на тиждень відзначили $35,2 \pm 3,3 \%$, рекомендовану кількість овочів щодня вживали лише $14,28 \pm 2,41 \%$ опитаних, фруктів - $15,24 \pm 2,48 \%$, солоні продукти обмежували $43,81 \pm 3,42 \%$. Характерним для державних службовців є порушення режиму харчування, причому в значної частини опитаних $-44,76 \pm 3,43 \%$ - основне приймання їжі припадало на вечірній час. Не визначено вірогідних відмінностей в основних характеристик харчування в державних службовців залежно від віку та статі ( $\mathrm{p}>0,05)$.

За результатами антропометрії надмірну масу тіла й ожиріння серед опитаних виявлено у $60,0 \pm 3,38 \%$ випадків (контрольна група $75,0 \pm 6,85 \%, \quad \mathrm{p}>0,05) ; \quad$ серед чоловіків -

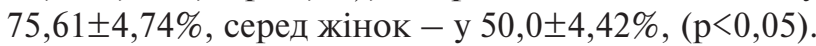
Надмірну масу тіла мали $36,19 \pm 3,32 \%$ опитаних $(50,0 \pm 5,52 \%$ чоловіків і 27,34 $\pm 3,94 \%$ жінок, $\mathrm{p}<0,05)$, ожиріння $-23,81 \pm 6,9 \%(25,61 \pm 4,82 \%$ чоловіків і $16,48 \pm 3,89 \%$ жінок, p>0,05). Поширеність ожиріння та надмірної маси тіла серед державних службовців чоловічої статі була вірогідно більшою, ніж серед жінок $(\mathrm{p}<0,05)$. Абдомінальне ожиріння за

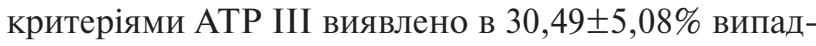
ків серед чоловіків і в $33,59 \pm 4,17 \%$ - серед жінок.

У відповіді на запитання «Оцініть у балах виконання Вами рекомендацій щодо здорового способу життя та профілактики захворювань» більшість державних службовців $(54,28 \pm 3,44 \%)$ зазначили на 
3 бали та менше за п’ятибальною шкалою. Основними чинниками, що перешкоджають впровадженню здорового способу життя для більшості опитаних $(72,86 \pm 3,07 \%)$ були звички та брак часу, $19,5 \pm 2,7 \%$ вказали причиною «Відсутність мотивації та підтримки». Не виявлено значущих відмінностей між чоловіками та жінками та в різних вікових групах. На питання «Чи є у Вас необхідність поповнити знання щодо профілактики серцевосудинних захворювань?» відповідь «так» отримано в $75,7 \pm 3,0 \%$ випадків - у 75,62 $\pm 4,74 \%$ серед чоловіків і в $75,78 \pm 3,79 \%$ серед жінок, у $72,3 \pm 3,8 \%$ випадків серед опитаних віком до 50 років $(70,0 \pm 6,5 \%$ чоло-

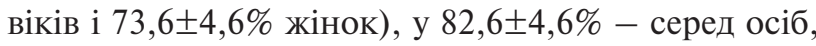
старших за 50 років $(84,4 \pm 6,5 \%$ чоловіків і $81,1 \pm 6,4 \%$ жінок). Серед запропонованих джерел для поповнення інформації щодо профілактики більшість державних службовців як чоловічої, так і жіночої статі обрали матеріали на веб-сайті ДНУ «НПКМ»

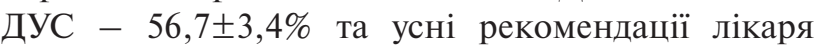
$(53,3 \pm 3,4 \%)$.

У ДНУ «НПЦ ПКМ» ДУС вперше впроваджено стандартизований підхід до визначення стадії готовності пацієнта до змін таких складових моделі поведінки, як тютюнокуріння, харчування та рівень фізичної активності у відповідності до транстеоретичної моделі (модель стадій змін). Лікар оцінює стадію готовності пацієнта до змін окремо для кожної зі складових моделі нездорової поведінки (тютюнокуріння, нездорового харчування, низького рівня фізичної активності) та залежно від отриманих результатів проводить диференційоване консультування, що дозволяє ефективніше використати час, відведений на прийом одного пацієнта. За результатами проведеного дослідження серед опитаних пацієнтів, які мають звичку тютюнокуріння, більшість - 40\% - перебувають на стадії обдумування, 35\% - на стадії дії, 15\% - на стадії перед-роздуму і 10\% - на стадії підготовки до дії. За результатами аналізу інформації щодо визначення стадії готовності до змін таких складових моделі поведінки, як харчування та рівень фізичної активності, виявлено, що понад половину опитаних перебували

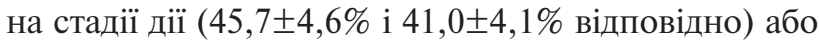
підготовки до дії $(24,1 \pm 4,0 \%$ і $20,1 \pm 3,4 \%$ відповідно) $[4,5]$.

У процесі комплексної оцінки поширеності ЧР серед державних службовців окремим блоком проведено аналіз перебігу артеріальної гіпертензії. За результатами клінічного обстеження артеріальну

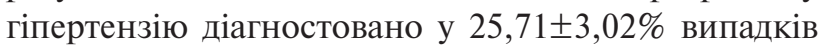
серед державних службовців $(32,93 \pm 5,19 \%$ серед

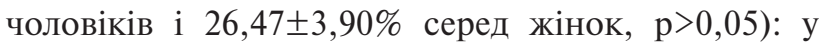
$9,93 \pm 2,52 \%$ серед осіб віком до 50 років, і в $57,97 \pm 5,94 \%$ серед старших за 50 років, що в цілому відповідає показникам в Україні. Важливо зауважи-

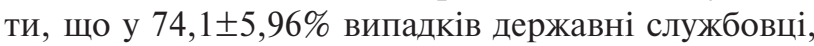
які мали артеріальну гіпертензію, досягли цільового рівня артеріального тиску, що значно перевищує відповідний показник в Україні (менше від 14\%) і доводить позитивний результат впровадження стандартизованих підходів до лікування артеріальної гіпертензії в ДНУ «НПЦ ПКМ» ДУС.

На другому етапі проведено розробку ЛПМД «Профілактика серцево-судинних захворювань». Розробку ЛПМД «Профілактика серцево-судинних захворювань» в ДНУ «НПЦ ПКМ» ДУС започатковано 2014 року як фрагмент комплексної науководослідної роботи. На момент планування науководослідної роботи в Україні були відсутні медикотехнологічні документи щодо профілактики СС3, існували лише клінічні рекомендації Асоціації кардіологів України [6], створені на підставі клінічних настанов Європейської асоціації кардіологів 2012 року [7]. Ми проаналізували клінічні настанови Європейської асоціації кардіологів щодо профілактики СС3 вуклінічній практиці [7], клінічні настанови NICE щодо оцінки ризику СС3 і заходів модифікаціїризику [8], клінічнінастанови Американської асоціації серця щодо заходів із модифікації стилю життя [9] і щодо корекції дисліпідемії [10]. За підгрунтя в розробці ЛПМД було взято клінічні настанови Європейської асоціації кардіологів 2012 року [7], інформацію, наведену у клінічних настановах, виданих пізніше 2012 року, було використано для уточнення стандартизованих підходів до профілактики СС3, які відповідають вимогам доказової медицини [8-10]. ЛПМД розроблено з урахуванням усього комплексу необхідних елементів медичної допомоги, стану основних фондів, забезпеченості кадровими та матеріальними ресурсами, організаційних методів роботи.

ЛПМД «Профілактика ССЗ», впроваджений у ДНУ «НПЦ ПКМ» ДУС, включав такі розділи:

1. Організація надання медичної допомоги.

2. Виявлення ЧР ССЗ і визначення рівня ризику.

3. Корекція ЧР (заходи немедикаментозної корекції та медикаментозна корекція).

4. Моніторинг ЧР / диспансерний нагляд.

Результати ситуаційного аналізу можливостей практичної реалізації заходів із доведеною ефективністю засвідчили, що у ДНУ «НПЦ ПКМ» ДУС заходи щодо виявлення ЧР, визначення рівня ризику та фармакологічної корекції проводяться як на рівні лікарів первинної допомоги - дільничних терапевтів Центру первинної медичної допомоги (ЦПМД), які проводять щорічні профілактичні огляди прикріпленого контингенту, так і лікарямифахівцями. Зокрема, лікарі-кардіологи терапевтич- 
ного відділення консультативно-діагностичного центру (КДЦ) забезпечують диспансерне спостереження пацієнтів з ішемічною хворобою серця дуже високого ризику та призначають заходи корекції, переважно - медикаментозної, лікарі ендокринологічного відділення КДЦ призначають заходи корекції цукрового діабету, лікарі неврологічного відділення КДЦ - заходи корекції пацієнтам з ураженням нервової системи. Проблемним питанням були недостатня увага лікарів до використання стандартизованих підходів визначення рівня ризику та призначення заходів немедикаментозної корекції $[11,12]$. Ці питання було враховано в ході розробки ЛПМД. Зокрема, у розділі «Організація медичної допомоги» окремим пунктом виділено проведення в ДНУ «НПЦ ПКМ» ДУС заходів щодо підвищення поінформованості медичного персоналу про сучасні аспекти профілактики СС3 і технології проведення профілактичного консультування.

В ЛПМД «Профілактика СС3» перелік дій лікаря і процесів представлено у вигляді таблиці (із зазначенням лікаря або відділення, відповідального за його виконання), а детальний опис етапів алгоритм оцінки та моніторингу ЧР, заходів корекції, динамічного диспансерного спостереження наведено у додатках. У додатках до ЛПМД також надано методичну інформацію для лікарів про проведення профілактичного консультування: «Принципи проведення профілактичного консультування», «Принципи ефективного спілкування для оптимізації зміни способу життя», «Проведення консультування щодо здорового харчування», «Проведення консультування щодо фізичної активності», «Проведення консультування щодо припинення тютюнокуріння», «Проведення консультування щодо надмврної маси тіла та ожиріння» $[13,14]$.

У впровадженому ЛПМД реалізовано підхід, який відповідає сучасним вимогам доказової медицина [7-10, 15] - основний обсяг заходів щодо визначення ризику та корекції ЧР проводиться лікарями ЦПМД у ході диспансерних і профілактичних оглядів [13, 14]. Ефективна профілактика CC 3 є можливою лише за умов мультидисциплінарного підходу [15]. Тому в ЛПМД було внесено опис заходів, які проводяться лікарями-фахівцями КДЦ - кардіологами, ендокринологами та неврологами. До переліку обов'язкових заходів увійшли підтримка мотивації пацієнта на виконання засад здорового способу життя та медикаментозного лікування й обов'язкове направлення пацієнтів, у яких не досягнуто оптимального контролю ЧР, лікарями-фахівцями до дільничного терапевта або іншого профільного фахівця.
ЛПМД «Профілактика ССЗ», як і інші ЛПМД, що впроваджуються у закладі, розміщено у внутрішній електронній мережі, що надає можливість доступу до цих матеріалів кожного лікаря - у ДНУ «НПЦ ПКМ» ДУС лікарі ЦПМД, КДЦ і стаціонарних підрозділів працюють з електронною медичною карткою амбулаторного хворого на автоматизованих робочих місцях (АРМ), вусі АРМи об’єднано за допомогою внутрішньої мережі, що надає можливість здійснення електронного документообігу.

Підвищення поінформованості пацієнтів є важливою складовою залучення їх до самоконтролю ЧР і дотримання здорового способу життя, сприяє збільшенню прихильності до виконання рекомендацій лікаря щодо корекції ЧР. Тому питання підвищення поінформованості пацієнтів і залучення їх до участі в профілактичних заходах стали фрагментом виконання етапу НДР щодо створення інформаційного блоку «Здоровий спосіб життя та профілактика серцево-судинних захворювань». У виборі інформації враховували результати анкетування репрезентативної вибірки пацієнтів щодо наявності у них ЧР ССЗ і готовності до змін поведінкових ЧЗ [3, 4]. Інформаційний блок, розміщений на веб-сайті ДНУ «НПЦ ПКМ» ДУС (розділ «Пацієнту» підрозділ «Поради лікарів) [16], включає такі розділи:

1. Здоровий спосіб життя. Поради щодо дотримання здорової моделі поведінки.

2. Інформація щодо здорового харчування.

3. Підтримка оптимальної маси тіла.

4. Оцінка рівня фізичної активності.

Інформація, розміщена на веб-сайті, містить опис основних ЧР СС3, у тому числі складових моделі поведінки, які справляють доведений вплив на стан здоров'я та розвиток захворювань, і рекомендації щодо їх виявлення та корекції.

3 огляду на інноваційність запропонованих підходів основні положення розробленого в ДНУ «НПЦ ПКМ» ЛПМД було використано для створення медико-технологічних документів МO3 України - Уніфікованого клінічного протоколу медичної допомоги «Профілактика серцево-судинних захворювань», який затверджено Наказом МО3 України від 13.06.2016 р. № 564 [17].

\section{ВИСНОВКИ}

1. Результати комплексного дослідження засвідчили високу поширеність ЧР СС3 серед державних службовців різного віку. Найбільш розповсюджені поведінкові ЧР - брак вживання основних продуктів, які характеризують здорове харчування (рекомендоване вживання риби $-35,2 \pm 3,3 \%$ опитаних, рекомен- 
дована кількість овочів - 14,28 $\pm 2,41 \%$, фрук-

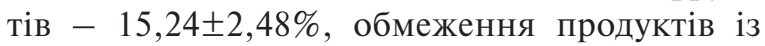
надмірним вмістом кухонної солі $43,81 \pm 3,42 \%)$, і гіподинамія $(59,05 \pm 3,4 \%)$. За результатами анкетного опитування в $54,28 \pm 3,44 \%$ випадків державні службовці оцінили виконання рекомендацій щодо здорового способу життя та профілактики захворювань за п'ятибальною шкалою на 3 бали та нижче, що обгрунтовує необхідність удосконалення профілактики СС3.

2. Доведено, що в 74, $1 \pm 5,96 \%$ випадків обстежені державні службовці, хворі на артеріальну гіпертензію, досягли цільового рівня артеріального тиску, що значно перевищує відповідний рівень в Україні (менше від 14\%) і доводить позитивний результат впровадження стандартизованих підходів до лікування артеріальної гіпертензії в ДНУ «НПЦ ПКМ» ДУС.

3. В ДНУ «НПЦ ПКМ» ДУС вперше в Україні з використанням переваг електронного документообігу впроваджено ЛПМД «Профілактика серцево-судиннихзахворювань». Запропоновані положення ЛПМД використано в розробці Уніфікованого клінічного протоколу медичної допомоги, затвердженого Наказом МO3 України від 13.06.2016 р. № 564.
4. Вперше розроблено спеціальний опитувальник для стандартизації підходів до визначення стадії готовності до змін окремо для основних поведінкових чинників ризику СС3 і проведення диференційованого профілактичного консультування. Пріоритетність використання опитувальника підтверджено патентом України (Пат. 114960 U Україна).

5. Удосконалено технології підвищення поінформованості державних службовців щодо здорового способу життя та профілактики серцевосудинних захворювань: на сайті ДНУ «НПЦ ПКМ» ДУС у розділі «Пацієнту. Поради лікарів» розміщено інформаційний блок «Здоровий спосіб життя та профілактика серцево-судинних захворювань», доступний для ознайомлення i роздрукування.

\section{ПЕРСПЕКТИВИ ПОДАЛЬШИХ ДОСЛІДЖЕНЬ}

Велике значення для подальшого впровадження в клінічну практику заходів із доведеною ефективністю щодо профілактики ССЗ належить використанню інформаційних технологій у медицині, зокрема, включення стандартизованих підходів до виявлення та моніторингу ЧР СС3 в електронну медичну картку амбулаторного хворого.

\section{ЛITEPATYPA}

1. Оцінка готовності пацієнта до змін окремих складових моделі нездорової поведінки: інформаційний лист № 360 / Г. З. Мороз, І. М. Гідзинська, І. М. Ткачук. K., 2017.4 c.

2. Про створення та впровадження медико-технологічних документів зі стандартизації медичної допомоги в системі Міністерства охорони здоров'я України : Наказ MO3 України від 28.09.2012 № 751. URL: http:// www.moz.gov.ua/ua/portal/dn_20121221_1118. html (дата звернення 17.03.2018).

3. Мороз Г. 3., Гидзинская И. Н., Мельничук Н. А. Распространенность факторов риска, связанных с образом жизни, у государственных служащих. Кардиология: от науки к практике. 2014. № 3. C. $5-12$.

4. Мороз Г. 3., Гідзинська І. М., Ласиця Т. С. Профілактичне консультування в практичній роботі лікаря. Therapia. Український медичний вісник. 2016. № 2. C. 44-48.

5. Мороз Г. 3., Гідзинська I. М., Ткачук I. М. Профілактичне консультування та оцінка індивідуальної стадії готовності пацієнта до змін окремих складових моделі нездорової поведінки. Украӥнський кардіологічний журнал. 2017. 1. С. 178.

6. Профилактика сердечно-сосудистых заболеваний: популяционная стратегия и индивидуализированные программы (на основе Европейских рекомендаций по профилактике сердечно-сосудистых заболеваний в клинической практике 2012). К.: МОРИОН, 2013. $96 \mathrm{c}$.
7. Perk J., Backer De G., Gohlke H. European Guidelines on cardiovascular disease prevention in clinical practice (version 2012). Eur Heart J. 2012. 33. P. 1635-1701.

8. Lipid modification: cardiovascular risk assessment and the modification of blood lipids for the primary and secondary prevention of cardiovascular disease. Issued: July 2014 last modified: January 2015: NICE clinical guideline 181. URL: http://guidance.nice.org.uk/cg181 (дата звернення 17.03.2018)

9. 2013 AHA/ACC Guideline on Lifestyle Management to Reduce Cardiovascular Risk: A Report of the American College of Cardiology/American Heart Association Task Force on Practice Guidelines / R. H. Ecke, J. M. Jakicic, J. D. Ard. Circulation. 2013. URL: http://circ.ahajournals. org/content/early/2013/11/11/01.cir.0000437740.48606. d1.full.pdf

10. 2013 ACC/AHA guidelines on the treatment of blood cholesterol to reduce atherosclerotic cardiovascular risk in adults. Circulation. 2013. URL: http://circ.ahajournals.org/ content/early/2013/11/11/01.cir.0000437738.63853.7.

11. Ласиця Т. С., Мороз Г. З., Гідзинська І. М., Дзізінська О. О. Оцінка та аналіз рівня знань і компетентності лікарів щодо профілактики серцево-судинних захворювань. Сучасні аспекти військової медицини: збірник наукових праць Головного військово-медичного клінічного центру «ГВКГ» МО України. К., 2015. Випуск 22. Ч. II. С. 40-45.

12. Ласиця Т. С., Мороз Г. З., Гідзинська І. М., Дзізінська О. О. Методологічні засади навчання та залучення медичних сестер до профілактики серцево-судинних 
захворювань. Сучасні аспекти військової медицини: збірник наукових праць Головного військово-медичного клінічного центру «ГВКГ» МО України. К., 2016. Випуск 23. С. 50-58.

13. Дячук Д. Д., Лисенко I. Ю., Мороз Г. З., Гідзинська I. М. Розробка локального протоколу медичної допомоги «Профілактика серцево-судинних захворювань»: теоретичні засади та практичні доробки. Лікарська справа. 2015. № 7-8. С. 163-167.

14. Мороз Г. З., Гідзинська I. М, Лисенко І. Ю., Ласиця Т. С. Запровадження стандартизованих підходів профілактики неінфекційних захворювань: роль локальних протоколів медичної допомоги. Збірка наукових праць наукової конференції з міжнародною участю: Запровадження Національного плану дій щодо неін- фекційних захворювань відповідно до Європейської стратегії «Здоров'я-2020: основи Європейської політики в підтримку дій держави і суспільства в інтересах здоров'я і благополуччя». Київ, 2015. С. 50.

15. 2016 European Guidelines on cardiovascular disease prevention in clinical practice / M. F. Piepoli, A. W. Hoes, S. Agewall et al. Eur Heart J. 2016. 37. P. 2315-2381.

16. Здоровий спосіб життя. URL: http://clinic.gov.ua/

17. Про затвердження та впровадження медико-технологічних документів зі стандартизації медичної допомоги в частині профілактики серцево-судинних захворювань: Наказ МО3 України від 13.06.2016 № 564. URL: http://mtd.dec.gov.ua/index.php/uk/reiestr$\mathrm{mtd} /$ item/ 71 - profilaktyka-sertsevosudynnykhzakhvoriuvan

\section{REFERENCES}

1. Moroz, G. Z., Gidzyns'ka, I. M., Tkachuk, I. M. (2017). Ocinka gotovnosti pacijenta do zmin okremyh skladovyh modeli nezdorovoi' povedinky : informacijnyj lyst № 360 [Evaluation of patient's readiness for changes in individual components of a model of unhealthy behavior: informational letter number 360]. K., 4.

2. Pro stvorennja ta vprovadzhennja medykotehnologichnyh dokumentiv zi standartyzacii' medychnoi' dopomogy v systemi Ministerstva ohorony zdorov'ja Ukrai'ny: Nakaz MOZ Ukrai'ny vid 28.09.2012 № 751. [About the creation and implementation of medical and technological documents on the standardization of medical care in the system of the Ministry of Health of Ukraine: Order of the Ministry of Health of Ukraine dated 28.09.2012 № 751]. Available at: http:// www.moz.gov.ua/ua/portal/ dn_20121221_1118.html (дата звернення 17.03.2018).

3. Moroz, G. Z., Gidzinskaja, I. N., Mel'nichuk, N. A. (2014). Rasprostranennost' faktorov riska, svjazannyh s obrazom zhizni, u gosudarstvennyh sluzhashhih [The prevalence of risk factors associated with the way of life in public servants]. Cardiology: from science to practice, 3, 5-12.

4. Moroz, G. Z., Gidzyns'ka, I. M., Lasycja, T. S. (2016). Profilaktychne konsul'tuvannja v praktychnij roboti likarja [Preventive counseling in the practice of a doctor]. Therapia. Ukrainian Medical Bulletin, 2, 44-48.

5. Moroz, G. Z., Gidzyns'ka, I. M., Tkachuk, I. M. (2017). Profilaktychne konsul'tuvannja ta ocinka indyvidual'noi' stadii' gotovnosti pacijenta do zmin okremyh skladovyh modeli nezdorovoi' povedinky [Preventive counseling and assessment of the individual stage of patient's readiness for changes in the individual components of a model of unhealthy behavior]. Ukrainian Cardiology Journal, 1, 178.

6. Profilaktika serdechno-sosudistyh zabolevanij: populjacionnaja strategija $i$ individualizirovannye programmy (na osnove Evropejskih rekomendacij po profilaktike serdechno-sosudistyh zabolevanij v klinicheskoj praktike 2012) [Prevention of Cardiovascular Diseases: Population Strategy and Individualized Programs (Based on European Guidelines for Cardiovascular Disease Prevention in Clinical Practice 2012)] (2013). К.: МОРИОН, 96 с.

7. Perk, J., Backer, De G., Gohlke, H. (2012). European Guidelines on cardiovascular disease prevention in clinical practice (version 2012). Eur Heart J., 33, 16351701.
8. Lipid modification: cardiovascular risk assessment and the modification of blood lipids for the primary and secondary prevention of cardiovascular disease. Issued: July 2014 last modified: January 2015: NICE clinical guideline 181. Available at: http://guidance.nice.org.uk/ $\operatorname{cg} 181$.

9. Ecke, R. H., Jakicic, J. M., Ard, J. D. (2013). AHA/ ACC Guideline on Lifestyle Management to Reduce Cardiovascular Risk: A Report of the American College of Cardiology. American Heart Association Task Force on Practice Guidelines. Circulation. 2013. Available at: http://circ.ahajournals.org/content/early/2013/ 11/11/01.cir.0000437740.48606.d1.full.pdf

10. 2013 ACC/AHA guidelines on the treatment of blood cholesterol to reduce atherosclerotic cardiovascular risk in adults (2013). Circulation. Available at: http://circ. ahajournals.org/content/early/2013/11/11/01. cir.0000437738.63853.7.

11. Lasycja, T. S., Moroz, G. Z., Gidzyns'ka, I. M., Dzizins'ka O. O. (2015). Ocinka ta analiz rivnja znan' i kompetentnosti likariv shchodo profilaktyky sercevosudynnyh zahvorjuvan' [Assessment and analysis of the level of knowledge and competence of doctors in terms of prevention of cardiovascular diseases]. Suchasni aspekty vijs'kovoi' medycyny : zbirnyk naukovyh prac' Golovnogo vijs'kovo-medychnogo klinichnogo centru «GVKG» MO Ukrai'ny. Vypusk 22, Ch. II, K., 40-45.

12. Lasycja, T. S., Moroz, G. Z., Gidzyns'ka, I. M., Dzizins'ka, O. O. (2016). Metodologichni zasady navchannja ta zaluchennja medychnyh sester do profilaktyky sercevo-sudynnyh zahvorjuvan' [Methodological bases of training and involvement of nurses in the prevention of cardiovascular diseases]. Suchasni aspekty vijs'kovoi' medycyny : zbirnyk naukovyh prac' Golovnogo vijs'kovo-medychnogo klinichnogo centru «GVKG» MO Ukrai'ny. Vypusk 23, K., 50-58.

13. Djachuk, D. D., Lysenko, I. Ju., Moroz, G. Z., Gidzyns'ka, I. M. (2015). Rozrobka lokal'nogo protokolu medychnoi' dopomogy «Profilaktyka sercevo-sudynnyh zahvorjuvan'»: teoretychni zasady ta praktychni dorobky [Development of the local protocol of medical care "Prevention of cardiovascular diseases": theoretical principles and practical developments]. Medical case, 7-8, 163-167.

14. Moroz, G. Z., Gidzyns'ka, I. M, Lysenko, I. Ju., Lasycja, T. S. (2015). Zaprovadzhennja standartyzovanyh pidhodiv profilaktyky neinfekcijnyh zahvorjuvan': rol' lokal'nyh protokoliv medychnoi' dopomogy [Introduction 
of standardized approaches to the prevention of noncommunicable diseases: the role of local medical aid protocols]. Zaprovadzhennja Nacional'nogo planu dij shhodo neinfekcijnyh zahvorjuvan' vidpovidno do Jevropejs'koi' strategii' «Zdorov'ja-2020: osnovy Jevropejs'koi' polityky $\mathrm{v}$ pidtrymku dij derzhavy i suspil'stva $\mathrm{v}$ interesah zdorov'ja i blagopoluchchja»: Zbirka naukovyh prac' naukovoi' konferencii' Z mizhnarodnoju uchastju. Kyi'v, 50.

15. Piepoli, M. F., Hoes, A. W., Agewall, S. (2016). European Guidelines on cardiovascular disease prevention in clinical practice. Eur Heart J., 37, 2315-2381.
16. Zdorovyj sposib zhyttja [Healthy Lifestyle]. Available at http://clinic.gov.ua/

17. Pro zatverdzhennja ta vprovadzhennja medykotehnologichnyh dokumentiv zi standartyzacii' medychnoi' dopomogy v chastyni profilaktyky sercevosudynnyh zahvorjuvan' [On approval and implementation of medical-technological documents on standardization of medical care in the part of prevention of cardiovascular diseases]: Nakaz MOZ Ukrai'ny vid 13.06.2016 № 564. Available at:http://mtd.dec.gov.ua/index.php/uk/ reiestr-mtd/item/71-profilaktyka-sertsevosudynnykhzakhvoriuvan

\section{Резюме}

\section{НАУЧНО-МЕТОДИЧЕСКОЕ СОПРОВОЖДЕНИЕ ВНЕДРЕНИЯ СТАНДАРТИЗИРОВАННЫХ ПОДХОДОВ К ПРОФИЛАКТИКЕ СЕРДЕЧНО-СОСУДИСТЫХ ЗАБОЛЕВАНИЙ В ПРАКТИЧЕСКУЮ ДЕЯТЕЛЬНОСТЬ ГОСУДАРСТВЕННОГО НАУЧНОГО УЧРЕЖДЕНИЯ «НАУЧНО-ПРАКТИЧЕСКИЙ ЦЕНТР ПРОФИЛАКТИЧЕСКОЙ И КЛИНИЧЕСКОЙ МЕДИЦИНЫ» ГОСУДАРСТВЕННОГО УПРАВЛЕНИЯ ДЕЛАМИ}

\section{Д.Д. Дячук, Г.з. Мороз, И.Н. Гидзинская, Т.С. Ласиця}

Государственное научное учреждение «Научно-практический центр профилактической и клинической медицины» Государственного управления делами, Киев

Цель - оптимизация мероприятий профилактики сердечно-сосудистых заболеваний (СС3) в Государственном научном учреждении «Научно-практический центр профилактической и клинической медицины» Государственного управления делами (ГНУ «НПЦ ПКМ» ГУА) в соответствии с требованиями доказательной медицины путем разработки и внедрения локального протокола медицинской помощи (АПМА) «Профилактика сердечно-сосудистых заболеваний».

Материал и методы. Проведено исследование распространенности факторов риска (ФР) ССЗ среди 210 государственных служащих. Разработку АПМА «Профилактика ССЗ» проводили согласно методологии, регламентированной Приказом МЗ Украины от 28.09.2012 г. № 751, с учетом потребностей и возможностей учреждения.

Результаты. По результатам анкетного опроса в 54,28 $3,44 \%$ случаев государственные служащие оценили выполнение рекомендаций по здоровому образу жизни и профилактике заболеваний по пятибалльной шкале на 3 балла и ниже. Среди ФР ССЗ наиболее распространенными были такие поведенческие ФР, как недостаточное употребление основных продуктов здорового питания (реко-

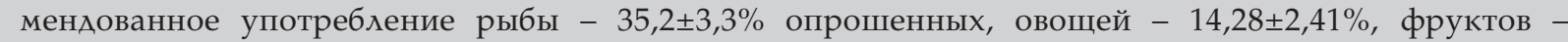

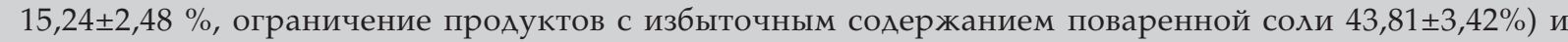
гиподинамия $(59,05 \pm 3,4 \%)$. При разработке $\Lambda$ ПМА основное внимание было уделено мерам по определению, коррекции и мониторингу ФР ССЗ врачами на всех этапах медицинской помощи. В перечень обязательных мероприятий вошли подлержка мотивации пациента на выполнение рекомендаций по здоровому образу жизни, медикаментозного лечения и достижения оптимального контроля ФР.

Выводы. В ГНУ «НПЦ ПКМ» ГУА впервые в Украине с использованием преимуществ электронного документооборота внедрили АПМА «Профилактика сердечно-сосудистых заболеваний».

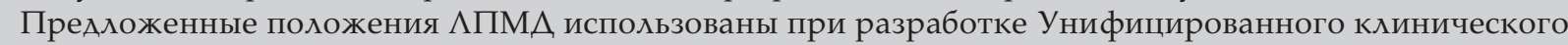
протокола медицинской помощи, утвержденного Приказом М3 Украины от 13.06.2016 г. № 564.

Ключевые слова: профилактика сердечно-сосудистых заболеваний, факторы риска, локальный протокол медицинской помощи. 


\section{Summary}

\section{INTRODUCTION OF STANDARDIZED APPROACHES TO CARDIOVASCULAR DISEASES PREVENTION IN CLINICAL PRACTICE OF THE STATE INSTITUTION OF SCIENCE "RESEARCH AND PRACTICAL CENTER OF PREVENTIVE AND CLINICAL MEDICINE" STATE ADMINISTRATIVE DEPARTMENT: SCIENTIFIC AND METHODOLOGICAL SUPPORT}

D.D. Dyachuk, G.Z. Moroz, I.M. Hydzynska, T.S. Lasitsya

Objective. Improvement of cardiovascular diseases (CVD) prevention in the State Institution of Science "Research and Practical Center of Preventive and Clinical Medicine" State Administrative Department (SIS "RPC PCM" SAT) in accordance to the requirements of evidence-based medicine via clinical pathway (CP) development and implementation.

Methods. We studied the prevalence of CVD risk factors (RF) in 210 state-owned employees. All participants completed a questionnaire on their smoking status, diet habits and physical activity level, results were reported as percentage.

The development of the clinical pathway "CVD Prevention" was made concordantly with the requirements of the Ministry of Health of Ukraine and taking into account the needs of our institution and suitability of existing facilities.

Results. We revealed that $54,28 \pm 3,44 \%$ of participants who completed a questionnaire evaluated their compliance with basic patterns of healthy lifestyle and diseases prevention on a five-point scale as 3 and below 3. The most common behavioral RF are unhealthy diet (only 35,2 $\pm 3,3 \%$ had recommended level of fish intake, $14,28 \pm 2,41 \%$ - vegetables intake, $15,24 \pm 2,48 \%$ - fruit intake, only 43,81 $\pm 3,42 \%$ restricted food high in salt) and low level of physical activity $(59,05 \pm 3,4 \%)$. The list of mandatory options in our CP "CVD prevention" included such phases and elements of care, as CVD RF assessment, intensive and structured intervention (risk management) and long-term follow-up for CVD prevention (monitoring) in all levels of health care, medical staff support of patient's motivation on healthy behavioral changes and compliance with drug therapy (adherence to medication) with the goal to achieve optimal RF control. The implementation of the CP "CVD Prevention" in our institution was made with the use of internal electronic network. The CP "CVD prevention" was used when working on the Ministry of Health guidance and pathways on the field of CVD prevention.

Conclusions. Clinical pathways "CVD prevention" is a tool to support the introduction of evidencebased medicine and use of clinical guidelines on CVD prevention in clinical practice for the purpose to improve patient's outcome.

Keywords: cardiovascular diseases prevention, risk factors, clinical pathway.

Інформація про авторів знаходиться в редакції.

Дата надходження до редакції 26.03.2018 р. 


\section{ДОДАТОК 1. АНКЕТА СОЦІОЛОГІЧНОГО ОПИТУВАННЯ}

Просимо Вас взяти участь у соціологічному опитуванні. Отримана інформація допоможе медичному персоналу нашої установи підвищити якість медичної допомоги. Просимо Вас позначити відповіді, що співпадають з Вашою думкою. Ваші відповіді не підлягають розголошенню. Дякуємо за співпрацю * - можливо декілька варіантів відповіді

\begin{tabular}{|c|c|c|c|c|c|}
\hline 1. Вік___ років & 2.Ч/Ж & \multirow{2}{*}{\multicolumn{2}{|c|}{$\begin{array}{l}\text { 3. Ваша вага ___ } \\
\text {; мати, сестра до } 65 \text { років) } \\
\text { хворобу? }\end{array}$}} & \multicolumn{2}{|c|}{ 4. Ваш зріст___ CM } \\
\hline \multicolumn{2}{|c|}{$\begin{array}{l}\text { 5.Чи хворіли Ваші рідні (батько, брат до } 55 \text { років; мати, сестра до } 65 \text { років) } \\
\text { на інфаркт, інсульт, стенокардію, гіпертонічну хворобу? }\end{array}$} & & & \multirow[b]{2}{*}{ мм рт.ст. } & ні \\
\hline \multicolumn{3}{|c|}{ 6. Який рівень артеріального тиску у Вас? } & & & Не знаю \\
\hline \multicolumn{3}{|l|}{ 7. Який рівень холестерину у Вас? } & \multicolumn{2}{|r|}{ ммоль/л } & Не знаю \\
\hline \multicolumn{2}{|l|}{ 8. Ви курите? } & так & нi & \multicolumn{2}{|c|}{ кинув _ _ років тому } \\
\hline $\begin{array}{l}\text { 9. Якщо Ви курите, чи маєте } \\
\text { намір позбавитись цієї звички? }\end{array}$ & $\begin{array}{c}5 \\
(\text { так) }\end{array}$ & $\begin{array}{c}4 \\
\text { (скоріше так) }\end{array}$ & $\begin{array}{l}3 \text { (важко } \\
\text { оцінити) }\end{array}$ & $\begin{array}{c}2 \\
\text { (скоріше ні) }\end{array}$ & $\begin{array}{c}1 \\
(\mathrm{Hi})\end{array}$ \\
\hline $\begin{array}{l}\text { 10. Чи дотримуєтесь Ви режиму } \\
\text { праці й відпочинку (сон }>7 \text { год., } \\
\text { вихідні, відпустка)? }\end{array}$ & $\begin{array}{c}5 \\
(\mathrm{TаK})\end{array}$ & $\begin{array}{l}4 \\
\text { (скоріше так) }\end{array}$ & $\begin{array}{c}3 \\
\text { (важко } \\
\text { оцінити) } \\
\end{array}$ & $\begin{array}{l}2 \\
\text { (скоріше ні) }\end{array}$ & $\begin{array}{c}1 \\
(\text { нi) }\end{array}$ \\
\hline $\begin{array}{l}\text { 11. Як Ви вважаєте, який рівень } \\
\text { психоемоційного навантаження } \\
\text { у Вас на роботі? }\end{array}$ & $\begin{array}{c}5 \\
\text { (високий) }\end{array}$ & $\begin{array}{c}4 \\
\text { (скоріше } \\
\text { високий) }\end{array}$ & $\begin{array}{c}3 \\
\text { (важко } \\
\text { оцінити) }\end{array}$ & $\begin{array}{c}2 \\
\text { (скоріше } \\
\text { низький) }\end{array}$ & $\begin{array}{c}1 \\
\text { (низький) }\end{array}$ \\
\hline \multicolumn{2}{|c|}{ 12. Ви ходите пішки або займаєтесь фізкультурою? } & \multicolumn{2}{|c|}{ Щоденно 30 хв/день та більше } & \multicolumn{2}{|c|}{ Менше 30 хв/день } \\
\hline $\begin{array}{l}\text { 13. Чи вважаєте Ви, що Ваше } \\
\text { харчування є збалансованим } \\
\text { та раціональним? }\end{array}$ & $\begin{array}{c}5 \\
(\text { так) }\end{array}$ & $\begin{array}{c}4 \\
\text { (скоріше так) }\end{array}$ & $\begin{array}{c}3 \\
\text { (важко } \\
\text { оцінити) }\end{array}$ & $\begin{array}{l}2 \\
\text { (скоріше ні) }\end{array}$ & $\begin{array}{c}1 \\
(\mathrm{Hi})\end{array}$ \\
\hline \multicolumn{2}{|c|}{ 14. Скільки разів на тиждень Ви їсте рибу? } & 2 та більше & 1 та менше & \multicolumn{2}{|c|}{ практично не вживаю } \\
\hline \multicolumn{3}{|c|}{$\begin{array}{l}\text { 15. Скільки порцій ( } 80 \text { г) свіжих овочів Ви споживаєте } \\
\text { щоденно? }\end{array}$} & 1 та менше & $1-2$ & більше 2 \\
\hline \multicolumn{3}{|c|}{$\begin{array}{l}\text { 16. Скільки порцій (80 г) свіжих фруктів Ви споживаєте } \\
\text { щоденно? }\end{array}$} & 1 та менше & $1-2$ & більше 2 \\
\hline 17. Споживання кухонної солі & $\begin{array}{c}\text { обмежую } \\
\text { солоні } \\
\text { продукти } \\
\end{array}$ & \multicolumn{2}{|c|}{$\begin{array}{l}\text { не замислююсь про кількість } \\
\text { солі в стравах }\end{array}$} & \multicolumn{2}{|c|}{$\begin{array}{l}\text { споживаю солоні страви } \\
\text { та досолюю їжу }\end{array}$} \\
\hline 18. Споживання солодощів & $\begin{array}{c}\text { обмежую } \\
\text { споживання } \\
\text { солодощів } \\
\end{array}$ & \multicolumn{2}{|c|}{$\begin{array}{l}\text { не замислююсь про кількість } \\
\text { цукру в продуктах }\end{array}$} & \multicolumn{2}{|c|}{$\begin{array}{l}\text { споживаю солодкі напої } \\
\text { та солодощі щоденно }\end{array}$} \\
\hline \multicolumn{3}{|l|}{ 19. Скільки разів на день Ви їсте? } & $1-2$ & $2-3$ & $3-4$ \\
\hline \multicolumn{3}{|l|}{ 20. Чи є Ваш сніданок повноцінним? } & так & не завжди & Hi \\
\hline \multicolumn{3}{|l|}{ 21. Чи є Ваш обід повноцінним? } & так & не завжди & ні \\
\hline \multicolumn{3}{|c|}{$\begin{array}{l}\text { 22. Чи часто у Вас основний прийом їжі припадає на вечірні } \\
\text { години? }\end{array}$} & так & не завжди & ні \\
\hline \multicolumn{2}{|c|}{$\begin{array}{l}\text { 23. Як Ви оцінюете загадьний стан Вашого } \\
\text { здоров' я }\end{array}$} & відмінний & добрий & задовільний & поганий \\
\hline $\begin{array}{l}\text { 24. Оцініть у балах виконання } \\
\text { Вами рекомендацій } \\
\text { щодо здорового способу життя } \\
\text { та профілактики захворювань }\end{array}$ & $\begin{array}{c}5 \\
\text { (виконую } \\
\text { завжди) }\end{array}$ & $\begin{array}{c}4 \\
\text { (переважно } \\
\text { виконую) }\end{array}$ & $\begin{array}{c}3 \\
\text { (важко } \\
\text { оцінити) }\end{array}$ & $\begin{array}{c}2 \\
\text { (переважно } \\
\text { не виконую) }\end{array}$ & $\begin{array}{c}1 \\
\text { (не виконую } \\
\text { ніколи) }\end{array}$ \\
\hline $\begin{array}{l}\text { 25. Що заважає Вам } \\
\text { дотримувати засад здорового } \\
\text { способу житт я? }\end{array}$ & $\begin{array}{l}\text { матеріальні } \\
\text { труднощі }\end{array}$ & $\begin{array}{l}\text { відсутність } \\
\text { необхідної } \\
\text { інформації }\end{array}$ & $\begin{array}{c}\text { відсутність } \\
\text { мотивації } \\
\text { та підтримки }\end{array}$ & звички & брак часу \\
\hline \multicolumn{4}{|c|}{$\begin{array}{l}\text { 26. Чи є у Вас необхідність поповнити знання щодо профілактики } \\
\text { серцево-судинних захворювань? }\end{array}$} & так & ні \\
\hline \multicolumn{2}{|c|}{$\begin{array}{l}\text { 27. Аля поповнення інформації щодо } \\
\text { профілактики для Вас зручніше отримати * }\end{array}$} & $\begin{array}{c}\text { роздруковані } \\
\text { інформаційні } \\
\text { матеріали }\end{array}$ & $\begin{array}{c}\text { усні } \\
\text { рекомендації } \\
\text { лікаря }\end{array}$ & \multicolumn{2}{|c|}{$\begin{array}{l}\text { матеріали на Інтернет сайті } \\
\text { нашої установи }\end{array}$} \\
\hline
\end{tabular}


Заповнюе лікар:

Аата № MKAX

IMT обхват талії AT

3XC Глюкоза Score

Прийом медикаментозних препаратів на момент обстеження: так/ні

Антигіпертензивні: так/ні

Статини: так/ні

медикаментозне Аікування цукрового діабету: так/ні

Аіагностовані та перенесені захворювання:

\begin{tabular}{|l|c|c|}
\hline Цукровий діабет & так & ні \\
\hline $\begin{array}{l}\text { IХС ( стенокардія, інфаркт міокарда, стентування, аортокоронарне шунтування, } \\
\text { серцева недостатність) }\end{array}$ & так & ні \\
\hline Артеріальна гіпертензія & так & ні \\
\hline $\begin{array}{l}\text { Цереброваскулярні захворювання (гостре порушення мозкового кровообігу, } \\
\text { транзиторні ішемічні атаки) }\end{array}$ & ні \\
\hline Захворювання нирок - діабетична нефропатія, хронічна ниркова недостатність & так & ні \\
\hline Оклюзивні ураження периферичних артерій & так & ні \\
\hline
\end{tabular}

